\title{
Periodismo es preguntar
}

José Manuel DE PABLOS COELLO.

Tenerife: Sociedad latina de Comunicación Social, 2011.

144 páginas

ISBN: 13: 978-84-939795-3-9

ISBN: 10: 84-939795-3-8

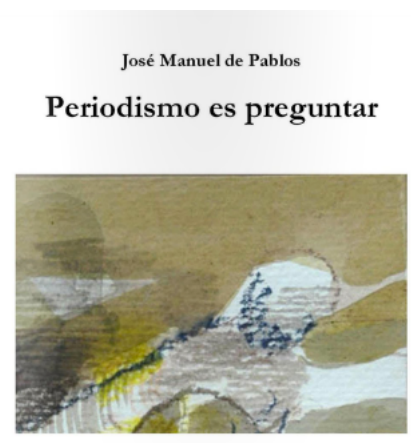

CAII

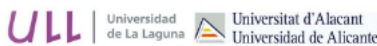
USC Latinä LCS

\section{Érica CERDEÑA*}

Universidad de La Laguna. España. erica_ftv@hotmail.com

La necesidad periodística de preguntar

To ask, a journalistic need

Los límites de lo que es información parecen estar bien delimitados. Sin embargo, a la hora de presentar un mensaje, el periodista tiene el deber de contrastar y preguntar cuando sea oportuno. Es algo que a menudo se olvida, incluso en los grandes medios de referencia. El catedrático de Periodismo de la Universidad de La Laguna José Manuel de Pablos quiere hacer hincapié en estas carencias que convierten a los grandes medios en servidores de nadie y promotores del amarillismo más descarado. José Manuel de Pablos es también doctor por la Universidad Complutense de Madrid. Allí, en Madrid ha podido formarse como profesional. Siendo su recorrido amplio, pasando por director de prensa en Canarias, ha podido constatar graves errores -no solo de estilo- en diarios de referencia en España como son El País, Abc o El Mundo. Ha querido advertir al lector de estas prácticas en su libro "Periodismo es preguntar". 
A lo largo de doce capítulos, el autor reproduce noticias reales, incluyendo fotografías, recortes de planas y declaraciones de diversas fuentes. En cada uno de estos aborda uno o dos temas que le sirven de herramienta para exponer el hilo de reflexión que "un buen periodista" debería plantear en cada uno de sus cometidos. Por ende, aclara el por qué a veces -más a menudo de lo debidono se sigue ese hilo conductor y se prefiere mirar para otro lado. Los intereses empresariales, el amarillismo, la especulación, el morbo y el divertimento son sustitutos de los principios deontológicos en la actualidad, para detrimento de esta profesión. "Antes, el Periodismo era preguntar y usar pocos adjetivos, sin adulación y sin entrega a la propaganda aceptada"l.

La palabra escrita siempre lleva una intención detrás. Lo mismo sucede con las fotografías. Como ejemplo encontramos en este libro la foto del ex militar Cavallo, acusado de torturador y enviado a España para su procesamiento, en la que aparece en "paños menores", práctica que De Pablos pone en conocimiento del lector ofreciendo un análisis minucioso del proceso previo y posterior a la publicación de la imagen de dudosa moral para ser publicada.

Otras cuestiones preocupantes son el "'machismo imperante" o la agenda setting, adoptadas por algunos medios como principios de selección informativa, tan arraigados ya en el seno de esta profesión. En palabras del autor, "esta alteración de las prioridades informativas habla de la flojera de las agendas internas de los medios".

El texto profundiza en relaciones de mayor calado que se han ido gestando a lo largo del tiempo y que ahora conforman una realidad constatable. Es así el caso de la relación preferencial que profesan diarios nacionales en favor del "amigo americano". Se llega a manipular la información hasta tal punto que un ente como la CIA puede ver sus notas de prensa publicadas en diarios españoles sin una sola coma cambiada. De Pablos cita en los capítulos 4 y 8 casos reales que ejemplifican esta teoría.

Sin cambiar el tono de denuncia ni su particular lenguaje coloquial, el autor identifica graves problemas de fondo en el tratamiento de las noticias. Así, plantea el debate de la utilización de términos como "terrorismo" o "democracia orgánica" por no ser representativos de la realidad, una única realidad. Si bien es cierto que la objetividad absoluta no existe en Periodismo, esta obra demuestra que hay formas más y menos apropiadas de acercarse a este imposible. Así, en ese debate cargado de preguntas que plantea el propio escritor -a lo largo de todo el libro, en un claro llamamiento a que sea oído que preguntar es necesario- sobre qué es terrorismo y qué no lo es, queda patente que terrorista se es según el ojo que esté mirando.

El logro de este libro es contar un problema -o muchos, según se mire- trascendental y contemporáneo de manera coloquial, con la firma del autor presente en todo momento. Utiliza el sarcasmo y la ironía para dinamizar la lectura y extraer del receptor su parte crítica y analítica respecto a las cuestiones tratadas. Como se dice 
anteriormente, además, a cada caso se le concede una tanda de preguntas que, de haber sido formuladas en su contexto ideal, no habrían derivado en una tarea pendiente para los medios que a sí mismos se consideran de "referencia".

En este sentido, la obra puede ser considerada una revisión del Libro de estilo de El País o Abc, pues toma ejemplos en sus mismas páginas para mostrar lo que no debe hacerse, algo que ellos mismos aclaran en estas guías para su plantilla de recursos humanos. No obstante, recordar cuáles son los márgenes del Periodismo -el bien hecho- es una tarea engorrosa que no todo el mundo está dispuesto a adjudicarse. $Y$, de hacerlo, puede que saque conclusiones muy semejantes a las que incluye "Periodismo es preguntar". 